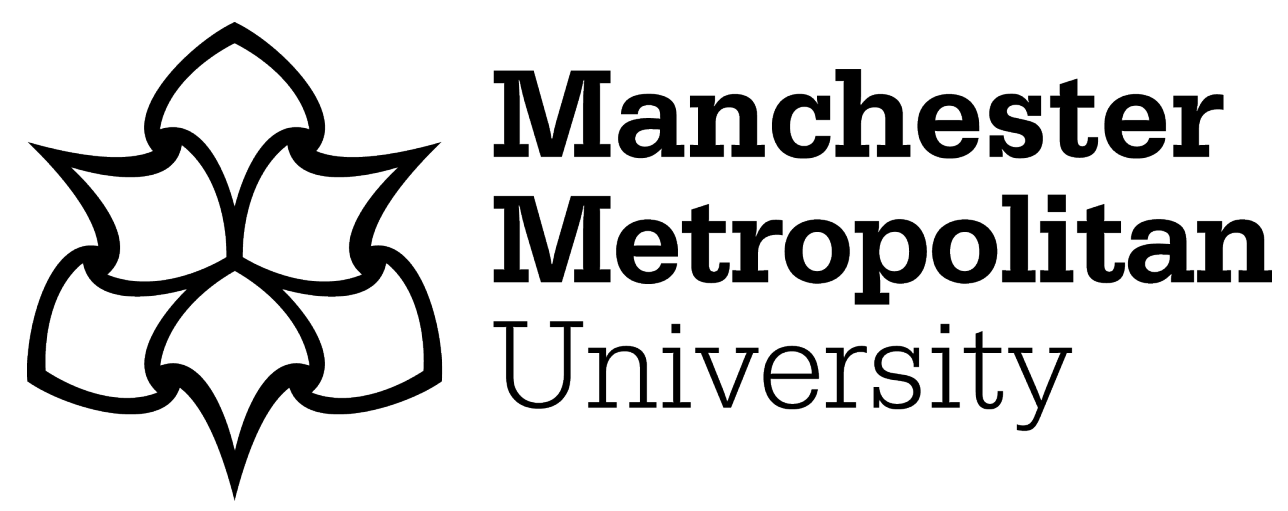

Leal Filho, Walter, Krishnapillai, Murukesan, Sidsaph, Henry, J. Nagy, Gustavo, M. Luetz, Johannes, Dyer, Jack, Otoara Ha'apio, Michael, Havea, Peni Hausia, Raj, Kushaal, Singh, Priyatma, Rogers, Tom, Li, Chunlan, K. Boodhan, Monica, Wolf, Franziska, Yayeh Ayal, Desalegn and Azadi, Hossein (2021) Climate Change Adaptation on Small Island States: An Assessment of Limits and Constraints. Journal of Marine Science and Engineering, 9 (6). ISSN 2077-1312

Downloaded from: https://e-space.mmu.ac.uk/627225/

Version: Published Version

Publisher: MDPI

DOI: https://doi.org/10.3390/jmse9060602

Usage rights: Creative Commons: Attribution 4.0

Please cite the published version 


\title{
Article \\ Climate Change Adaptation on Small Island States: An Assessment of Limits and Constraints
}

\author{
Walter Leal Filho ${ }^{1,2} \mathbb{D}^{\mathbb{D}}$, Murukesan Krishnapillai ${ }^{3} \mathbb{D}$, Henry Sidsaph ${ }^{4} \mathbb{D}$, Gustavo J. Nagy ${ }^{5}$, \\ Johannes M. Luetz ${ }^{6,7} \mathbb{D}$, Jack Dyer ${ }^{8}$, Michael Otoara Ha'apio ${ }^{9}$, Peni Hausia Havea ${ }^{10} \mathbb{D}$, Kushaal Raj ${ }^{11}$, \\ Priyatma Singh ${ }^{12}$, Tom Rogers ${ }^{13}$, Chunlan Li ${ }^{14,15,16, *}$, Monica K. Boodhan ${ }^{17}$ (D) Franziska Wolf ${ }^{1}$ (D), \\ Desalegn Yayeh Ayal ${ }^{18}$ (D) and Hossein Azadi 19,20 (D)
}

Citation: Leal Filho, W. Krishnapillai, M.; Sidsaph, H.; Nagy, G.J.; Luetz, J.M.; Dyer, J.; Otoara Ha'apio, M.; Havea, P.H.; Raj, K.; Singh, P.; et al. Climate Change Adaptation on Small Island States: An Assessment of Limits and Constraints. J. Mar. Sci. Eng. 2021, 9, 602. https://doi.org/10.3390/ jmse 9060602

Academic Editors: Achilleas Samaras and Ali Dastgheib

Received: 10 March 2021

Accepted: 11 May 2021

Published: 31 May 2021

Publisher's Note: MDPI stays neutral with regard to jurisdictional claims in published maps and institutional affiliations.

Copyright: (C) 2021 by the authors Licensee MDPI, Basel, Switzerland This article is an open access article distributed under the terms and conditions of the Creative Commons Attribution (CC BY) license (https:// creativecommons.org/licenses/by/ $4.0 /)$
1 Research and Transfer Centre "Sustainable Development and Climate Change Management", Hamburg University of Applied Sciences, Ulmenliet 20, D-21033 Hamburg, Germany; walter.leal2@haw-hamburg.de (W.L.F.); franziska.wolf@haw-hamburg.de (F.W.)

2 Department of Natural Sciences, Manchester Metropolitan University, Manchester M15 6BH, UK

3 Cooperative Research and Extension, College of Micronesia-FSM, Yap Campus, Colonia FM 96943, Yap, Micronesia; muru@comfsm.fm

4 Department of Management, Chester Business School, University of Chester, Chester CH1 4BJ, UK; h.sidsaph@chester.ac.uk

5 Instituto de Ecología y Ciencias Ambientales IECA, Facultad de Ciencias, Universidad de la República, Montevideo 11200,Uruguay; gnagy@fcien.edu.uy

6 School of Social Sciences, University of New South Wales, Sydney, NSW 2052, Australia; j.luetz@unsw.edu.au

7 School of Law and Society, University of the Sunshine Coast, Maroochydore, QLD 4556, Australia

8 University of Tasmania, Hobart, TAS 7005, Australia; Jack.Dyer@utas.edu.au

9 Institute of Ocean, Islands and Sustainable Development, Solomon Islands National University (SINU), Ranadi Campus, Honiara P.O. Box R113, Solomon Islands; mhaapio@gmail.com or drhaapiom@gmail.com

10 Live and Learn Tonga, Level 1, Tungi Colonnade, Nuku'alofa, Tongatapu 966, Tonga; ilaisiaimoana@yahoo.com

11 Climate Change and International Cooperation Division, The Ministry of Economy, Suva 11462, Fiji; kushaal_raj@hotmail.com

12 School of Science \& Technology, The University of Fiji, Lautoka 4245, Fiji; priyatmas@unifiji.ac.fj

13 School of Energy, Construction \& Environment, Faculty of Engineering, Environment and Computing, Coventry University, Coventry CV1 5FB, UK; tom.rogers@coventry.ac.uk

14 Center for Geopolitical and Strategic Studies \& Institute for Global Innovation and Development, East China Normal University, Shanghai 200062, China

15 Institute for Global Innovation and Development, East China Normal University, Shanghai 200062, China

16 School of Urban and Regional Sciences, East China Normal University, Shanghai 200241, China

17 Foundations and Prior Learning Unit, Department of Physics, The University of Trinidad and Tobago, Trinidad 724, Trinidad and Tobago, West Indies; monicakboodhan@gmail.com

18 Centre for Food Security Studies, College of Development Studies, Addis Ababa University, Addis Ababa 150129, Ethiopia; desalula@gmail.com

19 Department of Geography, Ghent University, 9000 Ghent, Belgium; hossein.azadi@ugent.be

20 Faculty of Environmental Sciences, Czech University of Life Sciences Prague, 16500 Prague, Czech Republic

* Correspondence: 15598022233@163.com

Abstract: Small Island States (SIDS) are among the nations most exposed to climate change (CC) and are characterised by a high degree of vulnerability. Their unique nature means there is a need for more studies focused on the limits to CC adaptation on such fragile nations, particularly regarding their problems and constraints. This paper addressed a perceived need for research into the limitations of adaptation on SIDS, focusing on the many unique restrictions. To this end, the study identified and described the adaptation limits they have by using a review of the literature and an analysis of case studies from a sample of five SIDS in the Caribbean and Pacific regions (Barbados, Trinidad and Tobago, Cook Islands, Fiji, Solomon Islands and Tonga). This research's findings showed that an adaptable SIDS is characterised by awareness of various values, appreciation and understanding of a diversity of impacts and vulnerabilities, and acceptance of certain losses through change. The implications of this paper are two-fold. It explains why island nations continue to suffer from the impacts of CC and suggest some of the means via which adequate policies may support SIDS in their efforts to cope with the threats associated with a changing climate. This study concluded that, 
despite the technological and ecological limits (hard limits) affecting natural systems, adaptation to CC is limited by such complex forces and societal factors (soft limits) that more adequate adaptation strategies could overcome.

Keywords: limits; adaptation; small island developing states; impacts; sustainable development; policy-making

\section{Introduction}

Small Island Developing States (SIDS) [1] was first recognised as a distinct group of developing countries facing particular social, economic and environmental vulnerabilities at the Earth Summit in 1992, especially in the context of Agenda 21 (Chapter 17 G). Since the Earth Summit, the United Nations (UN) discussed various international frameworks and measures to assist SIDS in their sustainable development efforts. This includes the Barbados Programme of Action, the Mauritius Strategy and the SAMOA Pathway [2-4], among others. SIDS are distinct from other developing countries in a variety of ways. Firstly, they have limited resources and access to technologies. Secondly, their economies are small and relatively fragile, heavily relying on tourism as a revenue source. In addition, they are characterised by a certain degree of vulnerability to climate change (CC) and its impacts [5].

Not only are SIDS particularly vulnerable to CC, but they also suffer severe financial losses when affected by climate change-related extreme events [6]. Many SIDS has used a scenario-based approach to evaluate possible impacts, vulnerability and CC adaptation, mainly in the first round of their national communications presented as part of their UNFCCC responsibilities. This approach is based on using outputs from general circulation models to provide scenarios for future CC. There are also global projections from the Intergovernmental Panel on Climate Change (IPCC) reports (e.g., The Fifth Assessment Report-also referred to as 'AR5'). The AR5 provides the updated status of knowledge regarding CC adaptation, which adjusts to the effects of current or expected climate conditions [7]. In the international context, SIDS are known as a group of 38 United Nations (UN) Member States and 20 Non-UN Member/Associate Members located in three regions including the Caribbean including the Pacific and the Atlantic, Indian Ocean, Mediterranean and South China Seas (AIMS) [8,9]. SIDS may differ significantly in culture, history, geography or socio-economic circumstances. However, they share several features that have led to the UN identifying them as a particular group that relies on the natural environment along with limited industrial activity, physical remoteness and limited scale economies [10-13]. Global CC continues to impact communities, ecosystems and many facets of the 65 million people who inhabit SIDS [14].

Given that SIDS have considerable portions of their populations in locations exposed to climate hazards, communities are highly vulnerable to the effects of CC [15]. The impacts of climate change are sea-level rise (SLR), changes in rainfall patterns, increased frequency and intensity of extreme weather events, ocean acidification and coral bleaching [16]. The accelerated increase in SLR has received much attention among the changes already observed. It leads to coastal erosion, deterioration of land and property, rise in flood frequency, saltwater intrusion and many ecological changes. A study by Leal Filho [17] stated the need to pay special attention to the impacts of CC on coastal areas on SIDS.

Low-lying SIDS are even more vulnerable to the effects of CC because they have relatively scarce natural resources and limited options for adaptation. The difference between adaptation constraints, obstacles, barriers and limitations in SIDS is not negligible; as Robinson [18] stated, the line is not separate and often, the word 'limit' is used as 'obstacle', constraint and/or 'barrier'. Based on her study, two main factors drive SIDS to their limits: the first is budget/income restriction (government expenditure) and the second is the characteristics of natural resources (availability). She discusses that the 
previous studies $[19,20]$ present different typologies of adaptation limits. Their typologies include physical and ecological, technological, social and economic limits. Physical and ecological limitations should be considered in this context as natural adjustment limitations, associated mainly with nature from ecosystem thresholds to geographical and geological limitations. Technological limitations occur when the "technology required for a specific method is not accessible or very expensive" or when the technology is simply unable to "maintain" the changes needed for a successful adaptation [19]. As Adger et al. [21] pointed out, social limits depend on the objectives of the adaptation of an actor, which are principles. The limits of individual and social drivers vary according to knowledge and ethics, culture and risk attitudes.

The economic limitations arise when the costs of adaptation exceed the costs of the averted impacts. CC also interacts differently along the coastlines of SIDS with various human activities and other drivers of change. Extreme weather and climate impact a wide range of SIDS-supporting economic activities such as agriculture and tourism and cause additional risks for many small islands and atolls at low altitudes [14]. Unfortunately, solutions to address these challenges remain elusive [22] because they often overlook the limits to adaptation $[16,22,23]$. Hence, this article discusses this issue. The subsequent parts of this paper will introduce and discuss SIDS's climate risks and outline their adaptation limits. In this way, the aims of this paper are as follows.

Firstly, the paper fosters a greater understanding of the main CC and climate-related hazards on selected examples of the Pacific and the Caribbean Small Island States. Secondly, it helps understand the ecological, economic, technological and social limits to adaptation, particularly in the SIDS. Thirdly, it presents some case studies on policymaking, influences and opportunities related to CC in Barbados, Cook Islands, Fiji, Solomon Islands, Tonga and Trinidad and Tobago as examples of SIDS. The novelty of the objectives lies in investigating projected CC impacts and vulnerabilities in the suggested case studies. More importantly, the study objectives attempt to address the most appropriate adaptation and resilient strategies and measures to mitigate the vulnerability of settlements, ecosystems and the economy in the coastline regions. Finally, the discussion focuses on several opportunities offered by CC, and the role of policies are discussed in detail. This study will contribute to a better judgment of policy contexts and suitable policy choices and present evidence on limits to adaptation and adaptive capacities crosswise the suggested case studies.

This study also provides the framework for understanding and exploring the unavoidable climate-related impacts on preventing and reducing future risks. Therefore, the study findings may help generate up-to-date information on how and where specific adaptation limits are addressed and losses and damages occur. Therefore, this study will help researchers, scientists and policymakers working in CC, SIDS and sustainability by strengthening the core scientific basis by focusing on the areas where climate adaption strategies are overlooked.

\section{Risks and Hazards and Opportunities Associated with Climate Change on SIDS}

It is now well established that SIDS are exposed to various climate-induced hazards increasing in frequency and severity. SIDS share several sustainable development challenges, despite their geographical and cultural diversity, including low resource availability, small but often rapidly growing populations, geographic isolation, exposure to hazards, excessive dependence on imports and susceptibility to global trade. Extensive ocean-atmosphere interactions such as trade winds, El Niño and the monsoons, tropical cyclones and hurricanes and especially SLR, influence the climate of SIDS. Combined with their socio-economic fragility, these climate features make SIDS one of the most vulnerable countries globally, and their inhabitants face a wide range of pressures.

The Fifth Assessment (AR5) of IPCC in 2014 provides scientific evidence that human impacts, especially greenhouse gas emissions, are the primary factor in global warming and resulting CC and SLR. A special report [24] warned about the many consequences of increased temperatures on coastal areas due to SLR. 
CC effects are linked to rapid occurrences, such as more frequent and severe storms and coastal flooding, and slow-onset processes, such as SLR land degradation and increased sea surface temperatures (SST). Phenomena such as ocean acidification and changes in the water cycle are also part of the process [14,16]. Failure to adapt and mitigate CC's impacts and the associated risks posed would lead to the loss of livelihoods, coastal settlements, infrastructure, ecosystem services and economic stability in many island communities [16]. Box 1 outlines some examples of threats and impacts of CC, SLR and climate-induced hazards in SIDS.

There are some examples of changing CC, sea-level rise, drivers and climate-related hazards and their associated impacts in the Pacific and Caribbean SIDS. SIDS are particularly vulnerable to marine climate changes due to their reliance on marine resources and the density of settlements in coastal regions. The future risks associated with the changing climate drivers (such as sea-level rise (SLR), increase in air/sea temperature and changing patterns of rainfall, and their current impacts) include loss of adaptive capacity and ecosystem services critical to lives and livelihoods in small islands [16].

There is a growing consensus that the extent and frequency of climate and climaterelated risks will increase as climate warming increases, especially on small islands [14]. Extreme weather and climate affect a wide range of economic activities that support the SIDS and pose an additional risk for many small, low-lying islands and atolls [14]. Much of the Pacific islands' population, infrastructure, agriculture and freshwater resources are situated in the coastal zone, vulnerable to sea-flooding, inundation, erosion and damage from tropical and extratropical cyclones. In addition, food supplies are at risk due to the islands' dependence on coastal fisheries $[6,25,26]$. Negative impacts of floods often occur mainly due to the lack of public understanding about the crucial role the drainage systems play during wet seasons. There is often a lack of regulatory frameworks for the construction sector [27].

A proper understanding of $\mathrm{CC}$ is a risk management challenge that opens up a wide range of opportunities to integrate adaptation with economic and social development and reduce future warming initiatives. The difficulty of designing appropriate CC response strategies and building public support for such strategies stems partly from the inherent complexity of the problem. Some of this complexity is associated with the physical science of CC, but there are also many social, economic, ethical and political challenges to understand and respond to CC [28]. The possibilities associated with CC in SIDS include the protection and enhancement of rural livelihoods and social wellbeing and the resilience of people, communities and ecosystems [29]. For countries worldwide, options include a mix of technology advance to reduce air pollution; develop investment in renewable energy, energy efficiency and public transport in urban areas; improve waste and water management; and enhance disaster planning [30].

\section{Limits to Adaptation}

CC adaptation is an ongoing process characterised by a high complexity [31]. Previous studies have suggested that even though adaptation methods may prevent possible impacts of CC, there are clear limits that inhibit their effectiveness. Thus, it is vital to identify and define these limits, as it can help improve adaptation methods and prevent maladaptation. The term "limits to adaptation" should not often be confused with "barriers to adaptation". The former refers to absolute thresholds [32], while the latter is mutable. Due to the specific characteristics of the persons concerned, the specific systems involved and the broader context underlying the operation of individuals and systems present limitations and obstacles to adaptation [33]. In other words, adaptation's most critical issues do not relate entirely to science but to the interaction of behaviours and institutions that facilitate such actions in the political, environmental, social and economic spheres. This indicates that adaptation in human systems is as crucial as the adaptation in natural systems and could, at least for the short term, be even more urgent [34]. For this paper, "limits to adaptation" is defined as Variable thresholds, making it challenging to implement climate 
change adaptation measures. An example of how these thresholds vary is the lack of a CC policy today, with no governance systems to implement CC adaptation. This may subsequently change when such a climate policy is prepared and implemented. So, the limits (initially imposed by the lack of a policy) are removed once it is in place.

Limits to CC adaptation can be broken down into both "hard" and "soft" categories [31]. Hard limits refer to thresholds existing in physical systems that may induce irreversible damage if exceeded. They are generally dependent on the rate of CC [7]. In ecosystems, for instance, hard limits may be associated with the inability to adapt to changes in climate since these exceed their physiological capacity (e.g., droughts). On the other hand, soft limits (e.g., technological and socio-economic options) may be described as those that may change over time.

In some cases, the options to overcome these limits may not be available initially. In the absence of means and space to move in exposed populations, some soft limits can become hard limits, particularly when intangible types of damage are taken into account. However, they may be developed in the future, unlike hard limits, which offer no such options [31,35]. Based on the study by Barnett et al. [31], some barriers can become limits in terms of adaptation; thus, some limits to adaptation can be overcome and converted into barriers to new technologies, cultures, values or governance systems. Mechler et al. [36] stated that in cases where hard limits are transgressed, financial, technical and legal support is necessary.

As described in Table 1, Figure 1 and below, there are four typical limits to CC adaptation:

(1) Ecological limitation: it refers to situations in which ecosystems and organisms face a decline in functionality and diversity due to their inability to adapt. A vital example of an ecological limit is coral bleaching. Healthy corals are typically able to survive in modestly warm temperatures. However, a slight rise above the average temperature may result in the occurrence of coral bleaching. Continued exposure to these higher temperatures may induce coral mortality [37]. A better understanding of the extent of the ecological limits leads to the proper policy selection based on Barnett's study [38], which could form a basis for monitoring changes and communicating conclusions covering all ecological areas.

(2) Economic limitation: it occurs when the financial costs for adaptation exceed the amount needed to fix the damages brought about by CC. Economic limits are seen, for instance, in adaptations initiatives concerning the rise of sea levels. The cost to protect surrounding areas from rising seas levels may be initially bearable. However, as the sea level rises and claims more areas, the cost of preserving the areas may sometimes exceed the value of the items being protected [37]. Mainly because the cost of damage to critical settlement facilities is even higher, the economic cost for SIDS will be a significant concern. In addition, the costs of rising sea levels will be high as a percentage of GDP, given the small size of SIDS economies [39].

(3) Technological limitation: it refers to cases where technology cannot avert the impacts of CC. A significant problem here is the difficulty in monitoring and evaluating some adaptation methods due to the lack of universal metric systems. CC impacts manifest in many ways, and the lack of multilateral systems to monitor adaptation methods is a further limit to adaptation $[18,40,41]$. Furthermore, research has demonstrated that insufficient technical capability encourages existing technology, providing little room for innovation and improvements. As CC worsens, the demand for low-cost, reliable and long-term technologies will increase. If not addressed, these may lead to adaptation deficits [42]. Mycoo's [39] study showed that the use of technology, land-use planning and ecosystem-based adaptation policies would involve droughtproofing Caribbean SIDS. A key conclusion of his research was that, given the limited capacity of human, technical and financial resources, prioritising practical adaptation options is essential for Caribbean SIDS.

(4) Social limitation: it occurs when people decide that adaptation methods have failed due to their inability to protect things they consider necessary. Adger et al. [21] sug- 
gested that four elements are inherent in any society that limit its effective adaptive response. Successful adaptation experiences resulting from the different social priorities and values could be modified or adapted in a different context. It was found that social limits were observed because adaptation efforts were influenced by external factors [32], which the local stakeholders cannot influence, such as global warming.

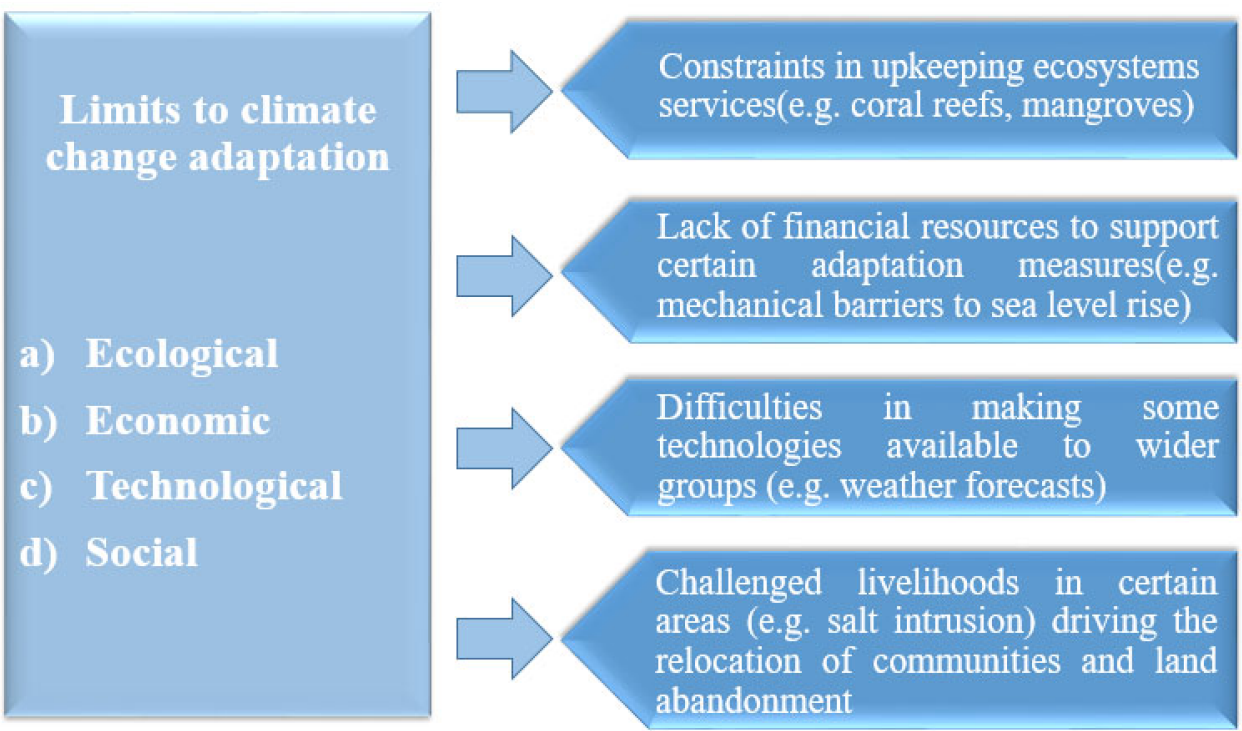

Figure 1. Examples of the limits to climate change adaptation.

Some recent studies have shown that many other unclassified limits exist regarding CC adaptation and human physiology. For instance, the temperature of the human body may reach fatal levels when exposed to extended periods of extreme heat [43]. A high percentage of the global population is at the moment exposed to heat events annually, and these induce numerous fatalities among the most vulnerable groups, such as the elderly or those with other chronic diseases. The percentage of fatalities is expected to increase by $48 \%$ in low emission cases and $74 \%$ in high emission cases [44].

Table 1. Four types of limitations to climate change adaptation.

\begin{tabular}{ll}
\hline Types of Limitation & Descriptions \\
\hline & Natural adaptation limitations, related mainly to the natural environment, ranging from \\
& ecosystem thresholds to geographical and geological limitations, include ecological and \\
physical limits. There is growing evidence that the resilience of socio-ecological systems & will be influenced by both the rate and magnitude of change and the fact that some \\
& systems may not be able to adapt to changing climate conditions without having their \\
& functional status and system integrity changed dramatically. Lakes, coral reefs, forests \\
& and arid lands, for example, have shown that smooth adaptation to change can be \\
& disrupted by unexpected and drastic changes in state, implying that an ecosystem's \\
& ability to withstand disturbance has a limit.
\end{tabular}

In essence, economic limits to adaptation occur when adaptation costs exceed the costs of the averted impacts. The high costs of protecting cities from sea-level rise against the costs of damage from sea-level rise are examples. In general, implementing adaptation measures entails a significant financial investment. Economic limits may also include a cultural aspect as well as a broader social one. For individuals, communities, groups or society as a whole, adaptation may not be culturally desirable. Costs may include both monetary and non-monetary values and the consideration of benefits associated with non-climate change. 
Table 1. Cont.

\begin{tabular}{|c|c|c|c|}
\hline & Types of Limitation & Descriptions & References \\
\hline 3 & Technological limitation & $\begin{array}{l}\text { When the technology to adapt to CC impacts is available but not on the scale required, } \\
\text { or when its application on the required scale is practically unfeasible, technological } \\
\text { limits to adaptation will take place. Protecting large-scale spatial areas from rising sea } \\
\text { levels is one example. Another example could be hard engineering options such as sea } \\
\text { walls and groynes with apparent limitations in technical options. If large-scale } \\
\text { transplantation is planned, coral transplantation techniques are undoubtedly limited in } \\
\text { technology considerations. The deployment location will determine the suitability of } \\
\text { any given technology for adaptation, the degree of CC and the country's or community's } \\
\text { current social, economic and environmental conditions, as well as management practices. } \\
\text { If non-climate factors that contribute to CC vulnerability are not addressed, } \\
\text { technological adaptation measures may only be partially effective. For example, } \\
\text { improving a water supply system technologically to ensure water availability during dry } \\
\text { spells will be of limited benefit to those who do not have access to it. }\end{array}$ & {$[19,20,48-50]$} \\
\hline 4 & Social limitation & $\begin{array}{l}\text { The social and cultural processes that govern how people react to climate variability and } \\
\text { change, whether in the form of prolonged drought, heavier and uncertain rainfall or } \\
\text { rising temperatures, are social limitations to CC adaptation. Individuals or groups are } \\
\text { prevented from seeking the most appropriate forms of adaptation by social limitations, } \\
\text { various processes relating to cognitive and normative restrictions. In this context, the } \\
\text { organisation and structure of social institutions are among the most important } \\
\text { considerations. The 'Rule Behaviour Savior' that govern belief systems, norms and } \\
\text { behaviour and organisational structure are taken to represent institutions in this } \\
\text { perspective. Social institutions are diverse and can be seen in local farmers' collectives } \\
\text { and indigenous knowledge institutions. }\end{array}$ & {$[21,46,47]$} \\
\hline
\end{tabular}

The inability to correctly define -and overcome- the limits to CC adaptation poses a considerable threat to the practical advancement of strategies and methods used in the future to curb the global climate crisis. It is vital to understand the limits to CC adaptation and the role of soft and hard adaptation approaches, which may be developed and deployed to reduce the impacts of CC.

\section{Methodology}

\subsection{Data Collection}

The methodological approach used two main approaches. The first method used was a comprehensive review of literature on CC on island nations. The second one analyses case studies from a SIDS sample in the Caribbean and Pacific regions, aiming to identify their limits to CC adaptation. The rationale behind this choice of methodology is two-fold. Firstly, it allows a comprehensive overview of the works published to date regarding $\mathrm{CC}$ on island nations. Secondly, they offer pertinent narratives of the CC mitigation and adaptation challenges they face.

Furthermore, the case studies identify and document various trends, providing an appraisal of the limits to adaptation experienced in each country. There is precedent for such a two-pronged approach in the literature [51]. Furthermore, and significantly, the case studies allowed for the literary analysis to complement empirical data provided by respondents who were consulted in individual SIDS case study locations [52,53]. In light of the research aims; conjoining both literary and grassroots-informed knowledge about the case studies may support SIDS in their efforts to better cope with the unique climate change challenges facing them $[54,55]$.

In the first step, the sampled countries, including Barbados, Trinidad and Tobago, The Cook Islands, Fiji, Solomon Islands and Tonga (Figure 2), have been selected.Table 2 shows the characteristics of these countries in terms of population, areas and GDP. This list of countries and case studies is not exhaustive, and each island State could be considered in greater depth and detail. However, this study is aimed at providing a realistic account of opportunity over the challenge. Thus, this study presents some relevant geographic information on SIDS and their limits to the adaptation of CC. The main reason for selecting these suggested case studies is to show the successes from which to learn and the gaps that need to be addressed for future development planning in SIDS. The examples from the 
Pacific include some of the larger SIDS, e.g., Fiji and Tonga. For instance, in the Caribbean SIDS, most data are available only in Spanish, making it challenging to collect and analyse for non-Spanish speakers.

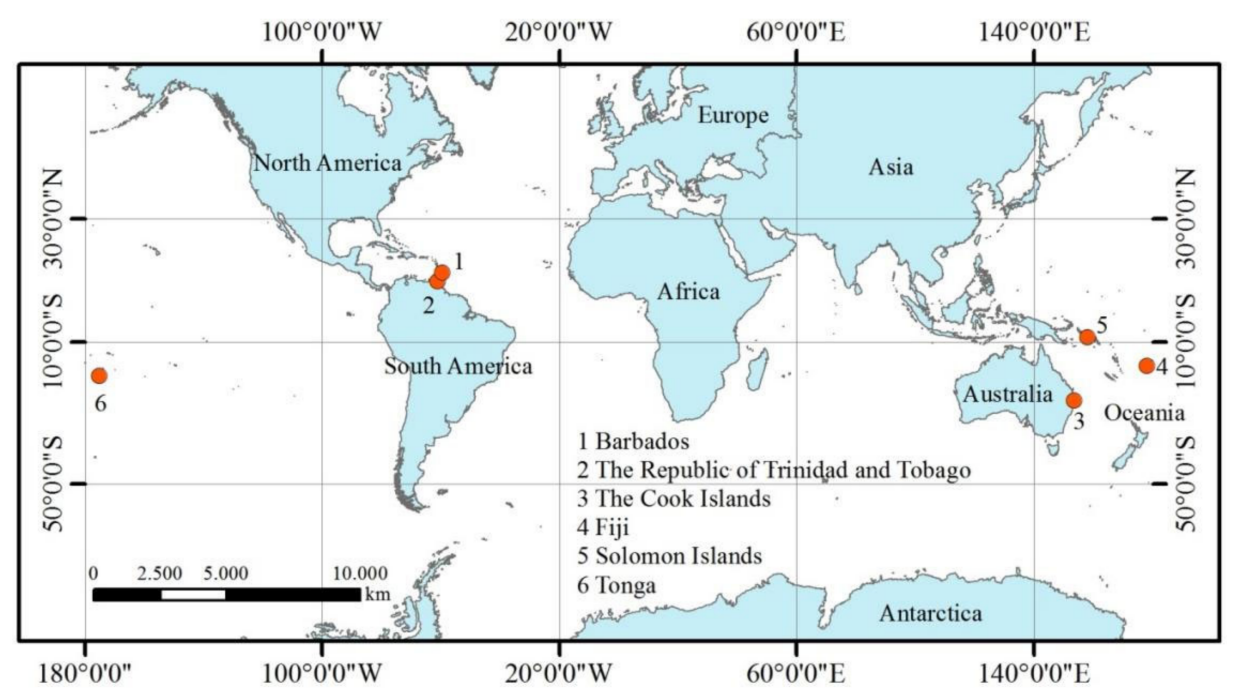

Figure 2. Schematic distribution of the six sampled islands.

Table 2. EM-DATA indicators.

\begin{tabular}{cccc}
\hline Country & Populations & Areas $\mathbf{( k m}^{\mathbf{2}} \mathbf{~}$ & GDP (\$) \\
\hline Barbados & 287,025 & 439 & 5398 billion \\
Trinidad and Tobago & $1,366,725$ & 5131 & 45.148 billion \\
Cook Islands & 17,459 & 236.7 & 363 million \\
Fiji & 926,276 & 18,274 & 9.112 billion \\
Solomon Islands & 652,857 & 28,400 & 1.479 billion \\
Tonga & 100,651 & 748 & 655 million \\
\hline
\end{tabular}

Nevertheless, Trinidad and Tobago is among the greatest SIDS, and relatively more information was available. Moreover, the most affected SIDS are located in the Caribbean, demonstrating the region's vulnerability to natural hazards (e.g., hurricanes). We took these inclusion criteria of vulnerability to CC into account as the starting point to focus expressly on Caribbean and Pacific Island region SIDS, given the low number of studies conducted in these regions.

In the second step, a comprehensive literature review was conducted to discuss critical aspects highlighting lessons learnt from and for CC adaptation in SIDS in different contexts. A broad search for relevant papers and reports on SIDS in different regions was conducted over the last 25 years (1994-2020) using significant research databases, including Google Scholar, Web of Science and Science Direct. The collection of secondary data includes the following significant keywords:

1. SIDS adaptation to climate change in the Caribbean and Pacific regions.

2. SIDS limits adaption and barriers.

3. SIDS soft and hard limits.

4. Typologies of SIDS adaptation limits.

Only research papers in English published in peer-reviewed international journals were the focus of the literature review. Furthermore, selected reports published by major international organisations, including the UN, the IPCC and the World Bank, were additionally accommodated in this research. Finally, the study focused on selected studies explaining specific issues related to the keywords, as mentioned earlier, while reducing the initial large number of papers drawn from various databases. 


\subsection{Qualitative Data Analysis}

As described in Figure 3, the transformation of descriptive (qualitative) data into (quantitative) measurements was achieved through a qualitative analysis involving multiple steps. The figure shows all the measures used to examine a wide range of topics associated with climate change adaptation in SIDS. As mentioned above and shown in Figure 3, the qualitative analysis was implemented through three main steps. The first step was to query research databases for relevant studies (1994-2020) from various sources (Google Scholar, Web of Science and Science Direct) and then narrowing the results down to those articles with specific keywords on SIDS and limits and barriers to climate adaptation. The second step involved further narrowing down the selection to studies with close links with Caribbean and Pacific regions. The third and final step was to select only those studies that focus on the vulnerability of Caribbean SIDS to warming beyond $1.5^{\circ} \mathrm{C}$.

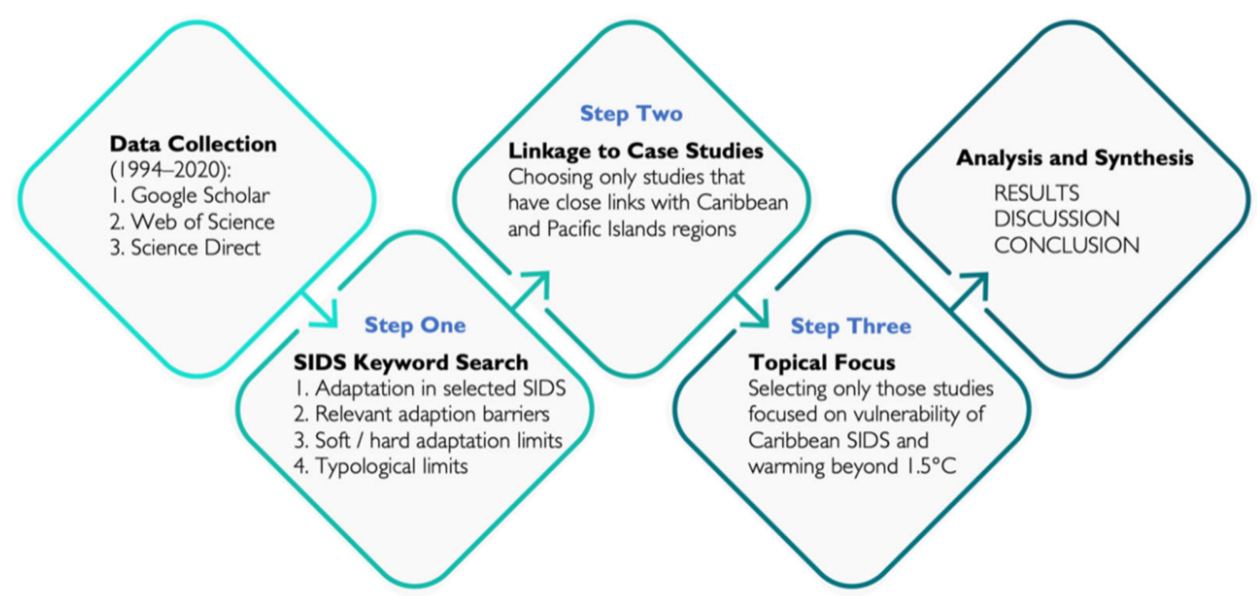

Figure 3. In-depth research process reflecting the main steps of data collection and analysis.

\section{Results}

Based on the data gathered from the sample, this section describes three main aspects:

1. The status of policymaking.

2. The limits to adaptation experienced.

3. Possible opportunities generated.

The first result obtained is related to policymaking. One of the fundamental requirements to CC adaptation is sound policies and policymaking, explicitly overseeing how a country handles CC management, both in mitigation and adaptation. In this context, an investigation of the availability of CC policies was undertaken, which is a matter of central concern in financial terms since-especially in developing countries-donor support is often dependent on the existence of well organisation adaptation priorities and frameworks.

Table 3 shows examples of the studied SIDS's main climatic characteristics (past and projected future impacts) and their climate management plans and policies. Most investigated SIDS have relevant CC plans and policies to face observed and projected climate impacts, although some are less comprehensive than they should be. The capacity and accuracy of climate studies have been significantly improved to implement appropriate policies, leading to a better understanding of ocean acidification's impact on coral reefs on natural systems such as zonal shifts and adverse effects [37]. Nevertheless, the information base is limited and usually not useful for national decision-making policies. In Barbados, the focus is on adaptation and mitigation strategies; so, there is a need for CC policy. Therefore, in the context of the CC Policy on Adaptation and Mitigation Strategies, in Barbados, inter-agency communication, coordination and (limited) jurisdiction of national institutions remain insufficient [56]. Trinidad and Tobago has a "National Climate Change Policy" and "Framework for the Development of a Renewable Energy Policy". It has been 
developedto promote mitigation and facilitate diversification of energy systems, discussing limits such as land arability/soil chemistry and topography, categorised as a physical and ecological limitation [57]. Moreover, Middelbeek et al. study revealed that Trinidad and Tobago's community receives minimal institutional support to withstand flooding [57].

The Cook Islands has already developed climate-disaster risk reduction strategies to deal with frequent exposure to cyclones [58]. Further, Climate impacts are entangled with traditional leadership, tourism and emerging Christian eco-theologies in Rubow [58] in the Cook Islands. In Fiji, national CC policies emphasise relocation from vulnerable areas [59]. In addition, adaptation to CC merges with risk management for disasters and community-based approaches. Nevertheless, there are specific technological limitations, such as modelling software/models and cell phone penetration, especially in the older demographic and more remote regions [60]. Recently, Solomon Islands has implemented adaptation programs (e.g., IFRC Preparednessfor CC programme (PCCP) and the WWF climate witness toolkit). However, CC adaptation programs do not consider the local level's knowledge and capacity, which is likely to lead to failure and maladaptation [61]; some approaches are built on traditional practices [62]. Thus, it is so important topay more attention to local knowledge. It was reported that in Tonga, technical resources and public education/awareness were primarily limited. In Tonga, the development of an indigenous knowledge system plays a significant role in supporting the advancement and execution of SDGs $[63,64]$ and preparing for drought conditions in advance. Higher education's current promotion would help students concede their problems and present sophisticated and innovative resolution strategies [65].

Table 3. Examples of past and projected future impacts and plans/policies on the investigated SIDS: Barbados, Trinidad and Tobago, The Cook Islands, Fiji, Solomon Islands and Tonga.

\begin{tabular}{|c|c|c|c|}
\hline SIDS & Past Impacts & Projected Future Impacts & $\begin{array}{l}\text { Climate Management and Development } \\
\text { Plans and Policies }\end{array}$ \\
\hline \multicolumn{4}{|c|}{ Overall } \\
\hline \multicolumn{2}{|c|}{$\begin{array}{l}\text { SIDS are highly vulnerable to marine climate changes due } \\
\text { to their reliance on the sea and the density of people on the } \\
\text { coast [16]. } \\
\text { Slow-onset climatic changes in SLR, regional air and water } \\
\text { temperatures (SST) increase compatible with global } \\
\text { warming, rainfall and acidification) cause coastal flooding, } \\
\text { erosion, saltwater intrusion, habitat and infrastructure loss } \\
\text { and damage, food supply shortages, people's displacement } \\
\text { and relocation and vector-borne diseases (VBD) } \\
\text { spread [16,24,26]. } \\
\text { Extreme weather events (EWEs) such as tropical cyclones } \\
\text { (TC), storm surges, droughts and inundation frequently } \\
\text { impacted the SIDS over the last few decades [16,24]. }\end{array}$} & $\begin{array}{l}\text { Climate change could modify EWE's } \\
\text { frequency and severity and change } \\
\text { the range and prevalence of } \\
\text { climate-sensitive diseases, particularly } \\
\text { VBDs in all SIDS [66]. } \\
\text { More peak winds and rainfall will } \\
\text { most likely increase significantly in } \\
\text { the South Pacific SIDSif average } \\
\text { temperatures rise by } 2{ }^{\circ} \mathrm{C} \text { compared to } \\
\text { if they only increase by } 1.5^{\circ} \mathrm{C}[24,67] \text {. }\end{array}$ & $\begin{array}{l}\text { National Adaptation Plans/Programmes in } \\
\text { Fiji; Solomon Islands; Trinidad and Tobago. } \\
\text { National Action Plan on Climate Change } \\
\text { Adaptation in Tonga. } \\
\text { National Sustainable Development Plan in } \\
\text { the Cook Islands. } \\
\text { Intended Nationally Determined } \\
\text { Contributions-NDCs in all the studied SIDS } \\
\text { The above plans and policies show that SIDS } \\
\text { combines climate adaptation with disasters } \\
\text { risks management and community-based } \\
\text { approaches to development. } \\
\text { Pacific SIDS encouraged ocean governance } \\
\text { and Sustainable Development Goal (SDG) } \\
\text { [68] through the NDCs [69]. }\end{array}$ \\
\hline Barbados & $\begin{array}{l}\text { SLR: Affected all the studied SIDS, } \\
\text { causing coastal erosion in } \\
\text { Barbados [56]. }\end{array}$ & $\begin{array}{l}\text { Projected likely changes in } \\
\text { temperature (air and SST) and the } \\
\text { frequency of extreme events are } \\
\text { expected to affect the island } \\
\text { highly [39]. }\end{array}$ & $\begin{array}{l}\text { A climate change policy focused on } \\
\text { adaptation—as a minimal contributor to } \\
\text { global emissions-and mitigation } \\
\text { strategies [70]. }\end{array}$ \\
\hline Cook Islands & $\begin{array}{l}\text { Increased SST, SLR } \\
\text { andacidification affected coral } \\
\text { reefs [71]. }\end{array}$ & $\begin{array}{l}\text { Coral reefs will be affected under } \\
\text { current climate change scenarios } \\
\text { continues [71]. }\end{array}$ & $\begin{array}{l}\text { The development of climate-disaster risk } \\
\text { reduction strategies-due to high exposure } \\
\text { to TC-to be effectively mainstreamed into } \\
\text { the enactment [72]. }\end{array}$ \\
\hline Fiji & $\begin{array}{l}\text { Extreme events and SLR lead to } \\
\text { inundation, declining fishery } \\
\text { stocks, agricultural produce and } \\
\text { water shortages [73], whereas } \\
\text { droughts associated with El Niño } \\
\text { facilitated seawater intrusion [74]. }\end{array}$ & $\begin{array}{l}\text { Projected SLR will likely endure } \\
\text { coastal degradation and damage [75]. }\end{array}$ & $\begin{array}{l}\text { National CC policies emphasise relocation } \\
\text { from vulnerable areas [59]. }\end{array}$ \\
\hline
\end{tabular}


Table 3. Cont

\begin{tabular}{|c|c|c|c|}
\hline SIDS & Past Impacts & Projected Future Impacts & $\begin{array}{l}\text { Climate Management and Development } \\
\text { Plans and Policies }\end{array}$ \\
\hline \multicolumn{4}{|c|}{ Overall } \\
\hline Solomon Islands & $\begin{array}{l}\text { The high observed SLR (above the } \\
\text { world's average) has permanently } \\
\text { inundated parts of the country, } \\
\text { leading to communities'relocation } \\
{[76,77] \text {. }}\end{array}$ & $\begin{array}{l}\text { Likely increases in SLR, tropical } \\
\text { cyclones (inundation) and El Niño } \\
\text { occurrence (droughts), and a very } \\
\text { likely increase in temperature would } \\
\text { heavily impact these vulnerable } \\
\text { islands [16]. }\end{array}$ & $\begin{array}{l}\text { Adaptation programs include the IFRC } \\
\text { Preparedness for CC Programme (PCCP) } \\
\text { and the WWF Climate Witness toolkit. Some } \\
\text { approaches are built on traditional } \\
\text { practice [62]. }\end{array}$ \\
\hline Tonga & $\begin{array}{l}\text { Both CC and EWES, particularly } \\
\text { SLR and the frequent sea-flooding } \\
\text { during the rainy and cyclone } \\
\text { seasons, affected habitat and } \\
\text { people's wellbeing [74]. }\end{array}$ & $\begin{array}{l}\text { The impacts on coastal communities } \\
\text { and the environment associated with } \\
\text { increasing SLR around the island over } \\
\text { the last few decades combined with } \\
\text { EWE's [78] will likely increase [16]. }\end{array}$ & $\begin{array}{l}\text { A policy-oriented to achieve the SDGs and } \\
\text { Sendai framework objectives }[79,80] \text { targets } \\
\text { building resilience by } 2035[65] .\end{array}$ \\
\hline Trinidad and Tobago & $\begin{array}{l}\text { (SST increases and seaweed } \\
\text { invasion [81] affected fisheries } \\
\text { and tourism industry [82]. }\end{array}$ & $\begin{array}{l}\text { Drought and sea flooding will likely } \\
\text { increase due to temperature increase, } \\
\text { SLR and rainfall and TCs reduction. } \\
\text { However, the frequency and intensity } \\
\text { of TCs will likely increase }[16,83] \text {. }\end{array}$ & $\begin{array}{l}\text { A "National Climate Change Policy" and } \\
\text { "Framework for the Development of a } \\
\text { Renewable Energy Policy" to promote } \\
\text { mitigation and facilitate diversification of } \\
\text { energy systems }[84,85] \text {. }\end{array}$ \\
\hline
\end{tabular}

A few examples of the positive influences of climate change are summarised in Table 4. As shown in Table 4, and according to Hohmeyer [86], in Barbadosand Tonga, the transformation of the energy system into renewable energy leads to improved economic conditions, improved air quality, employment and increased community-based cooperation. According to this table, CC's positive influences in Trinidad and Tobago are developing an intelligent climate and integrated renewable energy strategy. Another positive influence of CC is linked to the Cook Islands. As shown, adaptation projects have enabled the communities to restore their traditional farming methods to ensure food security. Climate adaptation projects have also led to justice, gender equality and women's employment as well. Based on results, in Fiji, CC has led young people to increase their knowledge and information. In addition, these catastrophes have caused the reconstruction of structures and the empowerment of these communities in the face of climate disasters. Rising temperatures and drought have also had positive effects on agriculture. For example, in the Solomon Islands, it has led to sustainable agriculture, the cultivation of resistant cultivars and better management of water resources. Therefore, it can be concluded that the impact of CC is not always negative. For example, CC may include greener rainforests and enhanced plant growth, increased vegetation in northern latitudes and possible increases in plankton biomass in some parts of the ocean.

Furthermore, since it is known that CC is also only characterised by limits but may also be associated with opportunities, respondents have been asked to list the most important ones, according to their opinions. The data is summarised in Table 5. As shown in Table 5, possible opportunities generated by CC are: (1) use of technologies to convert ocean heat energy, (2) increase production of quality seedlings and fertilizers, (3) production and use of plant resistant cultivars, (4) upgrade smart climate farming methods, (5) achieve more international budgets to increase adaptation capacity, (6) better land management, rangeland and natural resources, (7) economic and development achievements, (8) sustainable employment, (9) increasing resilience and flexibility and (10) combining indigenous and modern knowledge.

Apart from the data gathered and summarised in the previous tables, further results from the case studies are provided. These are as follows. 
Table 4. Positive influences of climate change.

\begin{tabular}{ll}
\hline Country & Positive Influences of Climate Change \\
\hline \multirow{3}{*}{ Barbados } & The transformation of the energy system into renewable energy would help in the: \\
(i) Intensification of the economy; (ii) Improvement of air quality; (iii) Generation of & employment options; and (iv) Community-based cooperation [86]. \\
Trinidad and Tobago & Diversification and establishment of renewable energy technologies [87]. \\
& Conversion of the current urban focus into climate-smart development [88] involves \\
& incorporating advanced Renewable Energy Technologies into the energy mix [89]. \\
& Early germination of mangoes in July [71]. \\
& 40\% increase in Skipjack tuna catch rates by 2035; numerous possible employment \\
& opportunities also flourish. \\
Adaptation Projects have enabled communities to restore their traditional farming \\
methods to ensure the constant supply of fresh food. \\
Climate adaptation Projects promoted gender equality and women's \\
employment [90]. \\
Awareness-raising and capacity building activities have endeavoured to engage \\
young people in various ways [91,92]. \\
The relief and development community of the island has built a perception for a \\
long time that "the best time to build back better and stronger is in the wake of a \\
disaster" [93,94]. \\
The warmer climate and changing rainfall seasons benefitted farmers [79,95]. \\
Temperature rise and drought imposed positive influences on people's agriculture, \\
which allows them to be engaged in planting drought and heat-tolerant crops \\
leading to sustainable agriculture [52]. \\
Temperature variations have enabled people to adapt better to respiratory diseases \\
and retain better health [96]. \\
The transformation of the energy system into renewable energy would help in the: \\
(i) Intensification of the economy; (ii) Improvement of air quality; (iii) Generation of \\
employment options and (iv) Community-based cooperation [86].
\end{tabular}

Table 5. Possible opportunities generated by climate change.

\begin{tabular}{|c|c|}
\hline Country & Possible Opportunities Generated \\
\hline Barbados & $\begin{array}{l}\text { The raised SST could be used as an advancement key to the ocean thermal energy } \\
\text { conversions technologies }[97,98] \text {. }\end{array}$ \\
\hline Trinidad and Tobago & $\begin{array}{l}\text { The seaweed invasion could be used as a bioenergy source [82] and manure for } \\
\text { producing better quality seedlings [81]. }\end{array}$ \\
\hline Cook Islands & $\begin{array}{l}\text { The introduction of heat and drought-resistant crops prototypes. Rainwater } \\
\text { catchment areas have been invested in promoting agriculture avenues. The maritime } \\
\text { sanctuaries are extended, and fishing restrictions are imposed [99]. A new Harbour } \\
\text { can endure up to } 500 \mathrm{~cm} \text { in SLR and Category } 5 \text { cyclones [100]. }\end{array}$ \\
\hline Fiji & $\begin{array}{l}\text { The Fijian government's lead role at COP } 23 \text { provided an opportunity to access } \\
\text { international funding to enhance adaptive capacity [101]. }\end{array}$ \\
\hline Solomon Islands & $\begin{array}{l}\text { New adaptation plans are inspired by the lessons learned from the } \\
\text { community-coordinated relocations in coastal proximity [77]. } \\
\text { The mainstreaming of disaster risk reduction measures should be integrated with } \\
\text { the newest (re)construction stages. It was learned that chiefs might be more } \\
\text { favourably disposed to their customary owned land for resettlement during the } \\
\text { crisis [102]. The economic and development gains may lead to growth, jobs and } \\
\text { long-term sustainable and climate resilience. }\end{array}$ \\
\hline Tonga & $\begin{array}{l}\text { Addressing climate-related hazards increased economic growth, job offers and } \\
\text { long-term resilience [79,103]. } \\
\text { Indigenous knowledge reduces food and water scarcity by storing and planting } \\
\text { drought-resistant crops and conserving water [63,64]. } \\
\text { Incidentally, the local populace is predominantly Christian by faith [52]; wherefore, } \\
\text { adaptation stakeholders may leverage faith-engaged approaches for effective and } \\
\text { locally meaningful responses to climate change [55]. }\end{array}$ \\
\hline
\end{tabular}

\subsection{Barbados}

The IPCC has projected significant alterations in Barbados weathers, including fluctuating rainfall, elevated air temperature and SST and increased daytime temperatures. The high probability and increased frequency of extreme catastrophic events are also expected, such as floods, droughts, SLR, heavy rains and intense tropical cyclone activity [16]. 
Additionally, the secondary impacts, including algal blooms of Sargassum seaweed [104], transcontinental dust clouds [105] and vector-borne diseases [106,107] have been observed.

\subsection{The Republic of Trinidad and Tobago}

The effects of CC on Trinidad and Tobago are multifaceted and impose its hazardous impacts on population health, agriculture, water resources, the ecology of coastal zones and tourism [81]. The negative impact of CC has resulted in SST increases, providing Sargassum seaweed with a suitable environment for expansion resulting in seaweed invasion and plaguing at islands' coastlines in 2015 [81]. This phenomenon impacted the local fisheries and tourism industry [82] as well as its cleaning process cost approximately USD 454,000 to Tobago [81]. Trinidad and Tobago are legislatively obliged to acquire a low carbon footprint because it has been a sanctioned signatory body of the Kyoto Protocol and the UN Framework Convention on CC [108].

\subsection{The Cook Islands}

The risks due to CC are multiple and high [64], including augmented ocean acidification and salinity, SLR, coral bleaching and disease, elevated salt spray pressure and increased sea surface, land and air temperature [109]. Despite the escalating intensity of cyclones and droughts for the Cook Islands and southeast Pacific, their frequency will be decreased [63,71,110]. A loss of around 36\% of Coral reefs from the 1990s to 2015 has been observed. Further, coral area eradication between $25 \%$ to $65 \%$ by $2030,50 \%$ to $75 \%$ (2055) and $90 \%$ to $100 \%$ by 2100 is predicted [71]; unless any strict actions are taken to restore coral reefs. The impact of coral reef extinction would be significant on marine ecology and the global economy. The eradication of the coral reef would lead to a $20 \%$ decline in the food supply in lower zooplankton, algae and primary biomass production. It will influence all other species by reducing marine habitats as well as interfering with marine ecology. For example, the Giant clams and green turtles may decline by $10-30 \%$. On the other hand, invertebrates, pearl, clam, trochus, milkfish and marine ornamental are considered coral-dependent species are projected to diminish by $50 \%$ by 2035 and $90-100 \%$ by 2100 if the current A1B scenario continues [71].

\subsection{Fiji}

The changing climate and related risks due to extreme climatic events have impacted the Fijian economy and environment (e.g., coastal inundation, SLR, declining fishery stocks, agricultural produce and water shortages [73]. Many developments and infrastructure, and human settlements in Fiji are located along with the coastal areas. They are projected to endure coastal degradation and damage due to SLR [75]. Fiji presided over Conference of Parties 23, hosted by the UNFCCC secretariat in Bonn, Germany, in November 2017. It was the first time a small Pacific Island country hosted one of the major international conferences. This is perhaps the most significant opportunity for Fiji to showcase its presence in the global community.

\subsection{Solomon Islands}

The Solomon Islands (SI) are highly susceptible to climate-induced alterations'adverse impacts [10]. Climatic events such as tropical cycle and related storms, changing precipitation patterns, droughts, SLRs, flooding in saltwater, heat stress and acidification of the ocean all threaten people's livelihoods and affect every economic sector of society [111,112]. The SI, located near the Pacific Ring of Fire, have a history of being affected by geophysical hazards. Therefore, coastal communities are well-acquainted with the risks and vulnerabilities of seaward exposure [113]. Moreover, the average local SLR is estimated to be 7-10 $\mathrm{mm}$ per year, which is equal to about three times the global average of $2.2 \mathrm{~mm}$ [78], thus situating local SLR in SI among the highest globally; several parts of the country are now submerged under the sea [76]. Secondary consequences of saltwater intrusion include the 
risk of food security crises [114]. As in the other parts of the SI archipelago, the compound effects of CC and other issues have resulted in the relocations of communities [77].

\subsection{Tonga}

The Tonga archipelago has been affected by CC induced impacts such as temperature rise, changing rainfall seasons, droughts $[74,115]$. However, increasing rainfall and humidity expedite the preservation of forest and mitigation through increasing carbon update, which in turn allows growth and development of young forests $[64,95,103]$. Table 1 summarises the status of policymaking in the sampled countries. It reflects that aspects of policymaking are relatively weak overall. The subsequent parts of this paper will offer a more in-depth analysis of the mechanisms which play a role in their policy processes.

\section{Discussion: The Opportunities Offered by Climate Change and the Role of Policies}

The findings presented here outlined the many pressures faced by SIDS. When crosschecked against the literature, they show that the economy and environment of SIDS have been impacted severely by climate extremes. Data from previous works [116] recognise that even grossly adverse aggravating circumstances may give rise to certain positive side-effects. These would be worth identifying and capitalising on even while efforts continue to ameliorate and redress the unavoidable and negative consequences of CC. Even thoughclimate change impacts island nations in significant ways, there is little data on response times. It is, however, clear that adaptation action is relatively urgent and cannot wait for long periods.

Focusing specifically on the environmental, climatic and sociocultural contexts of SIDS, this paper highlights pertinent opportunities that arise from case studies conducted in Barbados, The Republic of Trinidad and Tobago, The Cook Islands, Fiji, The Solomon Islands and Tonga. In an attempt to establish the context for the subsequent discussion, a range of opportunities are presented, some of which are straightforward and, to an extent, common-sense in their approach. However, they may serve the purpose of supporting the mitigation and adaptation efforts on island nations. Opportunities include the following possible prospects:

(a) Emphasis on education: progressive CC could benefit from an increased emphasis placed towards education, thereby strengthening the social and human capital, which can be expected to enhance efforts on in situ and ex-situ adaptation. This suggestion has already been advocated for atoll archipelagic environments elsewhere [117] and seems broadly transferable to the situation of SIDS generally. Opportunities in this area also include raising grassroots awareness and capacity in areas of communitybased adaptation (CBA). This extends from the construction of formal and informal settlements, the type of economic activities considered, correct knowledge on what to do in the event of extreme climate-related events, and the safeguarding in general of community resilience.

(b) Improved information: when stakeholders and policy-makers are informed of the issues pertinent to their continued survival, they are encouraged to become more engaged. Improved information needs to be accompanied by a systematic change in thinking and acting to facing these challenges in an anticipatory manner, which will take time to implement. Improved information needs to be accompanied by a systematic change in thinking and acting to facing these challenges in an anticipatory manner, which will take time to implement.

Some poor and highly vulnerable countries will have to adapt rather quickly to the adverse conditions created by CC.Such adaptation holds the promise that nations may leapfrog stages of development by adopting more advanced and sustainable technologies that can thereby accelerate the pace of implementing climate-smart innovations that can lead to an overall increase in the quality of life. Hence, opportunities are raised that offer prospects of reductions in economic and developmental disparities. Implementing policies intended to build capacities of nationals from SIDS to build, maintain, service and develop 
such leapfrog technology would be crucial to instituting more effective contingency plans in anticipation of future extreme weather events.

As SIDS continue to urbanise, there will be emergent opportunities to leverage higherdensity living for sustainable development. Reduced use of fossil fuels in transportation can contribute to global decarbonisation efforts and concurrently rebound more promptly from extreme weather events by lowering their supply-chain dependence on globally sourced fossil fuel imports.

It is also anticipated that the pace of adaptation overall will be accelerated. Such acceleration should lead to a more rapid regulation and mainstreaming of post-fossil fuel technologies and the transformation of energy systems through the ever-increasing uptake of alternative modes of transportation such as cycling and electric vehicles. Of course, the necessary infrastructure will need to be in place to cater for such changes, for example, electric vehicle charging points and roads, which cater more appropriately for cyclists. Given the high rates of motor vehicle accidents in many SIDS, enhanced road safety is a compelling prospect and opportunity.

The vulnerability of small island environments in the face of CC has already engendered significant commitments and public pronouncements on the part of some SIDS towards carbon neutrality. Such level of engagement demonstrates the intrinsic motivation and immediate investment on the part of low-lying archipelagic countries and communities to reduce their reliance on fossil fuel-derived development progressively. Thus, as wind farms and solar photovoltaic (PV) renewable energies are progressively mainstreamed, there will be opportunities to foster energy independence. Apart from reducing their dependence on importing fossil fuels, the increase in renewable energies can create a multiplier effect that can benefit entire economies if done to see revenue, job creation and societal benefits. This makes financial sense aside from mitigation and adaptation efforts in light of CC, as new commercial opportunities can help increase revenue in several ways (such as taxation and migration of skilled workforce).

Further, a host of opportunities may be found in the enlistment of private sector support for adaptation investments, including in areas of systems adaptation. Unfortunately, some SIDS will require intellectual and financial capital from other nations to implement mitigation and adaptation strategies. More intensive governmental and private relationships should be developed to bring relevant skills, technology, finance and infrastructure to a given island state. When public and private partnerships tackle the pressing issues facing some SIDS, this innovative approach can deliver some long-lasting impact and a diverse range of new opportunities may develop. The danger comes from the potential of exploitative relationships by one or more party members, whereby the interests of sustainable development are compromised for economic growth, which should be avoided.

Finally, in terms of paradigmatic approaches, it is conjectured that CC will further facilitate a shift in thinking from a predominantly reactionary to a more precautionary approach, also including disaster management [93,118]. By shifting the mindset of policymakers from dealing with challenges to leveraging opportunities, the result can shift the economies of SIDS onto more sustainable development trajectories. Of course, as extreme weather events continue to occur with increasing intensity and/or frequency, this may upset the kind of stable conditions required to promote change. Consequently, if a large proportion of resources is repeatedly spent recovering from events, it may be not easy to embrace this paradigm shift in policymaking. (The exposure of SIDS to financial challenges in the wake of disasters was powerfully exemplified in the Maldives' experience of the Boxing Day Tsunami, which saw the archipelagic nation incur "estimated total damages equal to $62 \%$ of the nation's Gross Domestic Product" [117] or after the hurricanes Maria and Irma in the Caribbean).

This is where a consortium of nations may stand to benefit from pooling their resources together to develop strategies and policies that can apply to many, if not all, SIDS. Instead of thinking in terms of national boundaries and territoriality, a SIDS-inclusive collaborative 
approach to sustainable development may be a way of systematically adopting measures that can (a) reduce their vulnerability and (b) increase their resilience to CC.

In short, the positions presented here are rather multifaceted and holistic, broadly delineating that the consequences of CC may be concurrently negative and yet offer opportunities. The analysis and synthesis presented by this case study suggest that it would be worth identifying and capitalising on opportunities, even while efforts continue to ameliorate and redress the unavoidable and negative consequences of CC.

Indeed, there will be complexities and limitations to the implementation of such opportunities. SIDS only have a finite amount of resources to rely upon. With many other pressing day-to-day, short-term challenges facing diverse stakeholders, duty bearers, policymakers and decision-makers, implementing and adapting these strategies will require a substantial commitment from individual states or a multi-state consortium.

Finally, a recent paper [5], based on summative content analysis techniques and semi-structured interviews with policy-makers, reported the limits of adaptation in the Caribbean SIDS. The primary limits are finance, technical capacity, data and records, natural resources and characteristics, human resources, knowledge and understanding of the effects of the climate. Some policies to address these constraints include (i) the depoliticization of CC; (ii) the prioritisation of good governance; (iii) the improvement of the access of SIDS to international financing for adaptation; and (iv) the road to a climate-resilient future through walking [5].

\section{Conclusions}

This paper provided an overview of the extent to which CC affected SIDS and outlined some of the limits experienced by island nations in coping with CC. The first part analysed the literature over the past 15 years on the vulnerability of small island states to CC. In contrast, the second part presented empirical case studies where readers can see the current trends. The third part outlined some of the necessary measures in small island states so that opportunities from CC can also be exploited. The main issue analysed in this study was "how and to what extent the challenges by human activities (e.g., agriculture and tourism) posed to SIDS could be addressed". These findings suggest that financing for adaptation and resilience-building is essential and urgent for SIDS, as they struggle to cope with the challenges posed by a changing climate.

These results also show that some limits need to be overcome. For instance, SIDS adaptation plans should look for funds to build their adaptive capacity, emphasising overcoming the problems (e.g., access to technologies) posed by economic constraints. In some cases, improved governance structures are needed to foster an adequate and sustainable adaptation of SIDS to climate change.

Due to the geophysical characteristics of SIDS, limiting global warming to 1.5 degrees may alleviate the pressures CC poses to them. However, it cannot exclude the risks of damage to ecosystems, infrastructure and properties, triggered by even lower temperature increases. This state of affairs suggests that, apart from global measures to mitigate CC by reducing $\mathrm{CO} 2$ emissions, it is crucial to design and implement suitable adaptation measures to allow SIDS to better cope with CC's short-term impacts. These measures, when properly implemented, can:

(1) Help to extend the limits to adaptation, reduce the effects of coastal erosion, saltwater intrusion, flooding and other phenomena, which currently pose a threat to the economies and livelihoods of inhabitants of small island nations.

(2) Help alleviate poverty influenced by unsuitable climatic conditions, which negatively influence economic activities and affect human wellbeing.

(3) Assist in reducing the hardships caused by extreme events, securing livelihoods and assisting in sustainable development.

(4) Foster territorial integration and cohesion by uniting the various parts of SIDS, which are often conceived in isolation. 
Our findings' crucial implication is that adaptation responses are underpinned by diverse and contested values, underpinned by social-economic, ecological and technological considerations, thus defining mutable and subjective adaptation limits. The authors believe that given the diverse values of different actors, there is a compelling need to recognise implicit and hidden values and interests before purposeful adaptation interventions (e.g., improving the livelihoods of inhabitants of small island nations). Consequently, we suggest that a governance framework is needed to recognise and address the complexity of the manifestation of territorial integration. In this way, this study argues that despite the technological and ecological limits (hard limits) affecting natural systems, adaptation to CC is limited by such complex forces and societal factors (soft limits) that could be overcome.

In terms of future perspectives, while global reactions to CC uncertainty and IPCC projections have primarily focused on mitigation, SIDS need to have targeted adaptation goals to handle existing and future risks. In addition, as temperatures increase, the exacerbation ofglobal warming puts SIDS at even greater levels of risk, calling for measures to increase their resilience and reduce their vulnerability,

The conceptual contribution of this study envisions that CC poses constraints as well as significant systematic opportunities. This paper has outlined some potential action areas through examples from various SIDS opportunities for CC mitigation and adaptation. Even though the current literature primarily focuses on the problems caused by or associated with CC, the paper emphasises how positive influences can generate multiple economic sectors opportunities. The presented case studies highlighted examples in agriculture, aquaculture, climate-proofing infrastructure, community development, education, health, migration, renewable energy, tourism and trade. For instance, higher land and sea surface temperature favour specific tourism destinations, alternative agricultural processes and drought-resistant crops can be mainstreamed rather than being seen as an alternative. The findings reported in this paper suggest that a resilient SIDS, therefore, relies on the (i) knowledge of different values, (ii) understanding of particular and variable impact vulnerabilities and (iii) acceptance through the changes in certain losses. The capacity to adapt is partly determined by technology and learning availability but mainly by treating vulnerable populations and places within the context of social decisions.

One of the crucial messages of this paper is whether existing limits may constrain communities' adaptation capacity; their impact can be reduced utilising proper processes that may address their drivers. For instance, improved policies and political frameworks may help address the technical and social barriers, whereas more coordinated action may improve the chances of tackling the economic ones. All in all, a better understanding of the limits to adaptation may provide a better basis upon which their impacts can be reduced. Adapting to increased risks minimises future disruption costs, increases recovery time and enhances resilience. Further research examining the CC opportunities in SIDS should seek better to understand the level of public support for such initiatives. Perceptions of decision and policymakers, of the business community and citizens should also be investigated to allow the development of fit-for-purpose policies for individual SIDS.

Furthermore, future research could also consider the potential for broader policy and strategy frameworks in SIDS and multi-stakeholder cooperation to maximise synergies and minimise duplications in respect of mitigation and adaptation efforts.

Author Contributions: The author contributes equally to the paper. All authors have read and agreed to the published version of the manuscript.

Funding: The APC was funded by Murukesan Krishnapillai.

Institutional Review Board Statement: Not applicable.

Informed Consent Statement: Not applicable.

Data Availability Statement: This is a review article and no data were reported.

Conflicts of Interest: The authors declare no conflict of interest. 


\section{References}

1. Lobendahn, M.D.K.; Mathieux, F.; Brissaud, D.; Evrard, D. Results of the first adapted design for sustainability project in a South Pacific small island developing state: Fiji. J. Clean. Prod. 2010, 18, 1775-1786. [CrossRef]

2. UN. The Barbados programme of action for the sustainable development of small island developing states. In Proceedings of the Global Conference on the Sustainable Development of Small Island Developing States, Bridgetown, Barbados, 26 April-6 May 1994.

3. UN. Report of the International Meeting to Review the Implementation of the Programme of Action for the Sustainable Development of Small Island Developing States 112; UN: New York, NY, USA, 2005.

4. UN. Report of the third International Conference on Small Island Developing States; UN: New York, NY, USA, 2014.

5. Robinson, S.-A. Adapting to climate change at the national level in Caribbean small Island developing states. Isl. Stud. J. 2019, 13, 79-100. [CrossRef]

6. Bush, M.J. Small Island Developing States, in Climate Change Adaptation in Small Island Developing States; Wiley Blackwell: Hoboken, NJ, USA, 2018. [CrossRef]

7. IPCC, About the Fifth Assessment Report (AR5); Intergovernmental Panel on Climate Change: Geneva, Switzerland, 2016. Available online: http:/ / www.ipcc.ch/ (accessed on 18 January 2018).

8. UN-OHRLLS. UN Office of the High Representative for the Least Developed Countries, Landlocked Developing Countries and Small Island Developing States; UN-OHRLLS: New York, NY, USA, 2018.

9. UN-OHRLLS. Small Island Developing States in Numbers: Climate Change Edition 2015; UN-OHRLLS: New York, NY, USA, 2015. Available online: http:/ / unohrlls.org/custom-content/uploads/2015/12/SIDS-IN-NUMBERSCLIMATE-CHANGE-EDITION_ 2015.pdf (accessed on 3 November 2020).

10. Barnett, J. Dangerous climate change in the Pacific Islands: Food production and food security. Reg. Environ. Chang. 2011, 11, S229-S237. [CrossRef]

11. Connell, J. Islands at risk? In Environments, Economies and Contemporary Change; Edward Elgar: London, UK, 2013.

12. Connell, J. Vulnerable islands: Climate change, tectonic change, and changing livelihoods in the Western Pacific. Contemp. Pac. 2015, 27, 1-36. [CrossRef]

13. Thomas, A.; Baptiste, A.; Martyr-Koller, R.; Pringle, P.; Rhiney, K. Climate change and small island developing states. Annu. Rev. Environ. Resour. 2020, 12,8.

14. Wong, P.P.; Losada, I.J.; Gattuso, J.-P.; Hinkel, J.; Khattabi, A.; McInnes, K.L.; Sallenger, A. Climate Change 2014: Impacts, Adaptation and Vulnerability. Part A: Global and Sectoral Aspects. Working Group II. Contribution to the Fifth Assessment Report of the Intergovernmental Panel on Climate Change; Cambridge University Press: Cambridge, UK, 2014; pp. 361-409.

15. Leal Filho, W. Handbook of Climate Change Adaptation; Springer: Cham, Switzerland, 2015.

16. Nurse, L.A.; McLean, R.F.; Agard, J.; Briguglio, L.P.; Duvat-Magnan, V.; Pelesikoti, N.; Tompkins, E.; Webb, A. 2014. Small islands. In Climate Change 2014: Impacts, Adaptation, and Vulnerability. Part B: Regional Aspects. Contribution of Working Group II to the Fifth Assessment Report of the Intergovernmental Panel on Climate Change; Barros, V.R., Field, C.B., Dokken, D.J., Mastrandrea, M.D., Mach, K.J., Bilir, T.E., Chatterjee, M., Ebi, K.L., Estrada, Y.O., Genova, R.C., et al., Eds.; Cambridge University Press: Cambridge, UK, 2014; pp. 1613-1654.

17. Leal Filho, W. Climate Change Adaptation in Coastal Areas; Springer: Cham, Switzerland, 2018.

18. Robinson, S.A. Climate change adaptation limits in small Island developing states. In Limits to Climate Change Adaptation; Filho, W.L., Nalau, J., Eds.; Springer International Publishing: Cham, Switzerland, 2018; pp. 263-281.

19. Morgan, C.L. Limits to Adaptation: A Review of Limitation Relevant to the Project "Building Resilience to Climate Change Coastal Southeast Asia; IUCN: Gland, Switzerland, 2011.

20. Klein, R.J.T. Adaptation to climate change: More than technology. In Climate: Global Change and Local Adaptation Edition: NATO Science for Peace and Security Series C: Environmental Security Chapter: 9; Linkov, I., Bridges, T.S., Eds.; Springer: Cham, Switzerland, 2011.

21. Adger, W.N.; Dessai, S.; Goulden, M.; Hulme, M.; Lorenzoni, I.; Nelson, D.R.; Naess, L.O.; Wolf, J.; Wreford, A. Are there social limits to adaptation to climate change? Clim. Chang. 2009, 93, 335-354. [CrossRef]

22. Bruckner, M. Effectively addressing the vulnerabilities and development needs of small Island developing States. In CDP Background Papers 017; Department of Economics and Social Affairs: New York, NY, USA, 2013.

23. Shultz, J.M.; Kossin, J.P.; Shepherd, J.M.; Ransdell, J.M.; Walshe, R.; Kelman, I.; Galea, S. Risks, health consequences, and response challenges for small-island-based populations: Observations from the 2017 Atlantic hurricane season. Disaster Med. Public Health Prep. 2019, 13, 5-17. [CrossRef]

24. IPCC. Global Warming of $1.5^{\circ} \mathrm{C}$; IPCC: Geneva, Switzerland, 2018.

25. Kelman, I.; West, J. Climate change and small island developing states: A critical review. Ecol. Environ. Anthropol. 2009, 5. [CrossRef]

26. Howes, E.L.; Birchenough, S.; Lincoln, S. Impacts of climate change relevant to the Pacific Islands. Pac. Mar. Clim. Chang. Rep. Card Sci. Rev. 2018, 1-19. Available online: https:/ / reliefweb.int/.../resources/1_Climate_change_overview.pdf (accessed on 11 November 2020).

27. Chmutina, K.; Bosher, L. Risk reduction or risk production: The social influences upon the implementation of DRR into construction project in Barbados. Int. J. Disaster Risk Reduct. 2015, 13, 10-19. [CrossRef] 
28. IPCC. IPCC Expert Meeting on Climate Change, Food, and Agriculture; Meeting Report; Mastrandrea, M.D., Mach, K.J., Barros, V.R., Bilir, T.R., Dokken, D.J., Edenhofer, O., Field, C.B., Hiraishi, T., Kadner, S., Krug, T., et al., Eds.; IPCC: Geneva, Switzerland, 2015; pp. 1-68.

29. FAO. FAO Assesses the Impact of Hurricanes Irma and Maria on Agriculture Sector in Antigua and Barbuda, Dominica and St. Kitts and Nevis. 2017. Available online: www.fao.org/americas/noticias/ver/en/c/1043252/ (accessed on 10 October 2017).

30. Attri, S.D.; Tiwari, S.; Ray, K. Challenges and opportunities of climate change and sustainable agriculture: A review. Vayu Mandal 2017, 43, 23-37.

31. Barnett, J.; Evans, L.S.; Gross, C.; Kiem, A.S.; Kingsford, R.T.; Palutikof, J.P.; Pickering, C.M.; Smithers, S.G. From barriers to limits to climate change adaptation: Path dependency and the speed of change. Ecol. Soc. 2015, 20, 1-11. [CrossRef]

32. Evans, L.S.; Hicks, C.C.; Adger, W.N.; Barnett, J.; Perry, A.L.; Fidelman, P.; Tobin, R. Structural and psycho-social limits to climate change adaptation in the Great Barrier Reef Region. PLoS ONE 2016, 11, e0150575. [CrossRef]

33. Moser, S.C.; Ekstrom, J.A. A framework to diagnose barriers to climate change adaptation. Proc. Natl. Acad. Sci. USA 2010, 107, 22026-22031. [CrossRef]

34. Barnett, J.; Palutikof, J.P. The limits to adaptation. In Applied Studies in Climate Adaptation; John Wiley \& Sons, Ltd.: Hoboken, NJ, USA, 2014; pp. 231-240.

35. Vaha, M. Hosting the small island developing states: Two scenarios. Int. J. Clim. Chang. Strateg. Manag. 2018, 10, 229-244. [CrossRef]

36. Mechler, R.; Singh, C.; Ebi, K.; Djalante, R.; Thomas, A.; James, R.; Tschakert, P.; Wewerinke-Singh, M.; Schinko, T.; Ley, D.; et al. Loss and damage and limits to adaptation: Recent IPCC insights and implications for climate science and policy. Sustain. Sci. 2020, 15, 1245-1251. [CrossRef]

37. Schmutter, K.; Nash, M.; Dovey, L. Ocean acidification: Assessing the vulnerability of socio-economic systems in small island developing states. Reg. Environ. Chang. 2017, 17, 973-987. [CrossRef]

38. Barnett, J. Adapting to climate change in Pacific Island countries: The problem of uncertainty. World Dev. 2001, 2, 977-993. [CrossRef]

39. Mycoo, M.A. Beyond $1.5^{\circ} \mathrm{C}$ : Vulnerabilities and adaptation strategies for Caribbean Small Island developing states. Reg. Environ. Chang. 2018, 18, 2341-2353. [CrossRef]

40. Hoad, D. Reflections on small island states and the international climate change negotiations (COP21, Paris, 2015). Isl. Stud. J. 2015, 10, 259-262.

41. Grydehøj, A.; Kelman, I. The eco-island trap: Climate change mitigation and conspicuous sustainability. Area 2017, 49, 106-113. [CrossRef]

42. Van den Homberg, M.; McQuistan, C. Technology for Climate Justice: A Reporting Framework for Loss and Damage as Part of Key Global Agreements Loss and Damage from Climate Change; Springer: Berlin/Heidelberg, Germany, 2019; pp. 513-545.

43. Wheeler, N.; Watts, N. Climate change: From science to practice. Curr. Environ. Health Rep. 2018, 5, 170-178. [CrossRef]

44. Mora, C.; Dousset, B.; Caldwell, I.R.; Powell, F.E.; Geronimo, R.C.; Bielecki, C.R.; Louis, L.V. Global risk of deadly heat. Nat. Clim. Chang. 2017, 7, 501. [CrossRef]

45. Scheffer, M.; Carpenter, S.; Foley, J.A.; Folke, C.; Walker, B. Catastrophic shifts in ecosystems. Nature 2001, 413, 591-596. [CrossRef]

46. Adger, W.N.; Agrawala, S.; Mirza, M.; Conde, C.; O’Brien, K.; Pulhin, J.; Pulwarty, R.S.; Smit, B.; Takahashi, K. Assessment of adaptation practices, options, constraints and capacity. In Climate Change 2007: Impacts, Adaptation and Vulnerability; Cambridge University Press: Cambridge, UK, 2007; pp. 717-743.

47. Jones, L. Overcoming Social Barriers to Adaptation; Overseas Development Institute: London, UK, 2010. Available online: http:/ / www.odi.org.uk/ resources / details.asp?id=4945\&title=social-barriers-climate-change-adaptation-nepal (accessed on 4 November 2020).

48. Reeder, T.; Lorenzoni, I.; O'Brien, K.L. Protecting London from tidal flooding: Limits to engineering adaptation. In Adapting to Climate Change Thresholds, Values, Governance; Cambridge University Press: Cambridge, UK, 2009; pp. 54-63.

49. Tompkins, E.L.; Adger, W.N. Building resilience to climate change through adaptive management of natural resources. Ecol. Soc. 2004, 9, 10. Available online: http:/ / www.ecologyandsociety.org/vol9/iss2/art10/ (accessed on 21 April 2021). [CrossRef]

50. Shortridge, J.E.; Zaitchik, B.F. Characterising climate change risks by linking robust decision frameworks and uncertain probabilistic projections. Clim. Chang. 2018, 151, 525-539. [CrossRef]

51. Leal Filho, W.; Ha'apio, M.O.; Luetz, J.M.; Li, C. Climate change adaptation as a development challenge to small Island states: A case study from the Solomon Islands. Environ. Sci. Policy 2020, 107, 179-187. [CrossRef]

52. Havea, P.H.; Jacot des Combes, H.; Hemstock, S.L.; Gee, K.; Han, D.; Khan, M.G.M.; Moore, T. Climate Change Impact on Livelihood, Health and Wellbeing: A Mixed Method Approach. PaCE-SD; University of South Pacific: Suva, Fiji, 2017.

53. Havea, P.H.; Hemstock, S.L.; Des Combes, H.J.; Luetz, J.M. “God and Tonga are my inheritance!”-Climate change impact on perceived spirituality, adaptation and lessons learnt from Kanokupolu, 'Ahau, Tukutonga, Popua and Manuka in Tongatapu, Tonga. In Climate Change Impacts and Adaptation Strategies for Coastal Communities; Leal Filho, W., Ed.; Springer: Cham, Switzerland, 2017; pp. 167-186. [CrossRef]

54. Leal Filho, W.; Nalau, J. Limits to Climate Change Adaptation; Springer: Cham, Switzerland, 2018. [CrossRef]

55. Luetz, J.M.; Nunn, P.D. Beyond Belief: Opportunities for Faith-Engaged Approaches to Climate-Change Adaptation in the Pacific Islands; Springer: Cham, Switzerland, 2021. [CrossRef] 
56. Mycoo, M.; Chadwick, J. Adaptation to climate change: The coastal zone of Barbados. Marit. Eng. 2012, 165. [CrossRef]

57. Middelbeek, L.; Kolle, K.; Verrest, H. Built to last? Local climate change adaptation and governance in the Caribbean-The case of an informal urban settlement in Trinidad and Tobago. Urban Clim. 2014, 8, 138-154. [CrossRef]

58. Rubow, C. Enacting cyclones: The mixed response to climate change in the Cook Islands. In The Social Life of Climate Change Models, 1st ed.; Hastrup, K., Skrydstrup, M., Eds.; Routledge: Oxfordshire, UK, 2013; Volume 8.

59. McNamara, K.E.; Des Combes, H.J. Planning for community relocations due to climate change in Fiji. Int. J. Disaster Risk Sci. 2015, 6, 315-319. [CrossRef]

60. Walshe, R.A.; Chang Seng, D.; Bumpus, A.; Auffray, J. Perceptions of adaptation, resilience and climate knowledge in the Pacific: The cases of Samoa, Fiji and Vanuatu. Int. J. Clim. Chang. Strateg. Manag. 2018, 10, 303-322. [CrossRef]

61. SPREP. Pacific Adaptation to Climate Change. Republic of the Marshall Islands, Project Proposal. Secretariat of the Pacific Regional Environment Programme. 2009. Available online: https://www.preventionweb.net/files/28165_sprep2009rmipacc.pdf (accessed on 5 November 2020).

62. Handmer, J. Adaptive Capacity: What Does It Mean; Imperial College Press: London, UK, 2003.

63. ABM. Climate Change in the Pacific: Scientific Assessment and New Research. Volume 2: Country Reports; National Library of Australia: Canberra, Australia, 2011.

64. ABM. Climate Variability, Extremes and Change in the Western Tropical Pacific: New Science and Updated Country Reports 2014; National Library of Australia: Canberra, Australia, 2014.

65. GOT. Tonga Climate Change Policy: A Resilience Tonga by 2035; GOT: Nuku'alofa, Tonga, 2016.

66. Ebi, K.L.; Lewis, N.D.; Corvalan, C. Climate Variability and Change and Their Potential Health Effects in Small Island States: Information for Adaptation Planning in the Health Sector. Environ. Health Perspect. 2006, 114, 1957-1963. [CrossRef] [PubMed]

67. Patricola, C.M.; Wehner, M.F. Anthropogenic Influences on Major Tropical Cyclone Events. Nature 2018, 563, 339-346. [CrossRef] [PubMed]

68. Quirk, G.; Hanich, Q. Ocean Diplomacy: The Pacific Island Countries' Campaign to the UN for an Ocean Sustainable Development Goal. Asia-Pacific J. Ocean Law Policy 2016, 1, 68-95. [CrossRef]

69. Gallo, N.D.; Victor, D.G.; Levin, L.A. Ocean commitments under the Paris Agreement. Nat. Clim. Chang. 2017, 7, 833-838. [CrossRef]

70. INDC. Barbados Intended Nationally Determined Contributions. Communicated to the UNFCCC on September $28,2015$. Available online: https://www4.unfccc.int/sites/ndcstaging/PublishedDocuments/Barbados\%20First/Barbados\%20INDC\% 20FINAL\%20September\%20\%2028,\%202015.pdf (accessed on 10 April 2021).

71. Newport, C.; Tutangata, T. Mangoes in July. Report on Cook Islands Public Service Climate Change. Functional Review and Institutional Structure Development. Pacific Climate Change Science Program. Australian Government. 2011. Available online: https: / / environment.gov.au/system/files/resources/746c10dd-59a4-43f4-b205-8151c4a11054/ files/mangoes-july.pdf (accessed on 12 November 2020).

72. CIG. Joint National Action Plan for Disaster Risk Reduction and Climate Change Adaptation 2011-2015; Cook Islands Government Press: Cook Island, New Zealand, 2012.

73. Ferris, E.; Cernea, M.M.; Petz, D. On the Front Line of Climate Change and Displacement: Learning from and with Pacific Island Countries; The Brookings Institution, London School of Economics: London, UK, 2011.

74. TMS. Climate Summary of Tonga; Tonga Meteorological Service, Government of Tonga: Fua'amotu, Tonga, 2016.

75. Voccia, A. Climate change: What future for small, vulnerable states? Int. J. Sustain. Dev. World Ecol. 2012, 19, 101-115. [CrossRef]

76. Albert, S.; Leon, J.X.; Grinham, A.R.; Church, J.A.; Gibbes, B.R.; Woodroffe, C.D. Interactions between sea-level rise and wave exposure on reef island dynamics in the Solomon Islands. Environ. Res. Lett. 2016, 11. [CrossRef]

77. Luetz, J.; Havea, P. We're not Refugees, We'll Stay Here Until We Die!"-Climate Change Adaptation and Migration Experiences Gathered from the Tulun and Nissan Atolls of Bougainville, Papua New Guinea; Springer: Cham, Switzerland, 2018.

78. Nunn, P.D. The end of the Pacific? Effects of sea level rise on Pacific Island livelihoods. Singap. J. Trop. Geogr. 2013, 34, 143-171. [CrossRef]

79. GOT. Tonga Strategic Development Framework 2015-2025-A More Progressive Tonga: Enhancing Our Inheritance; GOT: Nuku'alofa, Tonga, 2015.

80. UN. Sustainable Development Goals (SDGs); UN: New York, NY, USA, 2016.

81. Ramdwar, M.N.A.; Stoute, V.A.; Abraham, B.S. An evaluation of Sargassum seaweed media compositions on the performance of hot pepper (Capsicum chinense Jacq.) seedling production. Cogent Food Agric. 2016, 2. [CrossRef]

82. Milledge, J.J.; Harvey, P.J. Ensilage and anaerobic digestion of Sargassum muticum. J. Appl. Phycol. 2016, 28, 3021-3030. [CrossRef]

83. Christensen, J.H.; Kumar, K.K.; Aldria, E.; An, S.-I.; Cavalcanti, I.F.; Castro, M.; Zhou, T. Climate Phenomena and Their Relevance for Future Regional Climate Change, Supplementary Material. Climate Change 2013: The Physical Science Basis. Contribution of Working Group I to the Fifth Assessment Report of the Intergovernmental Panel on Climate Change, 62; Cambridge University Press: Cambridge, MA, USA, 2013. [CrossRef]

84. GOTT. National Climate Change Policy. Policy, Port of Spain: The Government of Trinidad and Tobago; GOTT: Port of Spain, Trinidad and Tobago, 2011.

85. Couture, T.; Gagnon, Y. An analysis of feed-in tariff remuneration models: Implications for renewable energy investment. Energy Policy 2010, 38, 955-965. [CrossRef] 
86. Hohmeyer, O. A $100 \%$ Renewable Barbados and Lower Energy Bills A plan to Change Barbados' Power 5; University of Flensburg: Flensburg, Germany, 2015.

87. MEEI. Consolidated Monthly Bulletins. January-December 2017; Ministry of Energy and Energy Industries (MEEI): Port of Spain, Trinidad and Tobago, 2017; Volume 54.

88. UN Habitat. Urbanisation and Climate Change in Small Island Developing States; UN Habitat: Nairobi, Kenya, 2015.

89. MoF. Budget Statement 2015; The Government of the Republic of Trinidad and Tobago: Port of Spain, Trinidad and Tobago, 2014.

90. ICCI. Current and Future Climate of Fiji Islands. Pacific International Climate Change Adaptation Initiative. Climate Change Science Program. 2011. Available online: https://www.pacificclimatechangescience.org/wp-content/uploads/2013/06/1_ PCCSP_Fiji_8pp.pdf (accessed on 11 November 2020).

91. Barnett, J.; Campbell, J. Climate Change and Small Island States: Power, Knowledge and the South Pacific; Taylor and Francis: London, UK, 2010.

92. Webb, J. Engaging Young People in the Solomon Islands for Red Cross Action on Climate Change; Red Cross Red Crescent: Geneva, Switzerland, 2008.

93. Luetz, J.M. Planet Prepare: Preparing Coastal Communities in Asia for Future Catastrophes, Asia Pacific Disaster Report; World Vision International: Bangkok, Thailand, 2008.

94. Ong, J.M.; Jamero, M.L.; Esteban, M.; Honda, R.; Onuki, M. Challenges in build-back-better housing reconstruction programs for coastal disaster management: Case of Tacloban City, Philippines. Coast. Eng. J. 2016, 58, 1640010. [CrossRef]

95. FAO. Asia and the Pacific National Forest Programmes Update 34 200; FAO: Rome, Italy, 2000.

96. WHO. Human Health and Climate Change in Pacific Island Countries; World Health Organization: Geneva, Switzerland, 2015; pp. 1-172. [CrossRef]

97. Singh, A.; Ephraim, J. Ocean energy: The new energy frontier for the Eastern Caribbean small island developing states. Energy Policy 2016, 99, 1-3. [CrossRef]

98. Kempener, R.; Neumann, F. Ocean Thermal Energy Conversion-Technology Brief; IRENE: Abu Dhabi, United Arab Emirates, 2014.

99. CIG. An Assessment of National Climate Change Priorities Alignment to the Regional Framework; Cook Islands Government Press: Cook Island, New Zealand, 2012.

100. Asian Development Bank. Cook Islands: Aviatu Port Development Project; Asian Development Bank: Mandaluyong, Philippines, 2015.

101. COP23 Fiji. How Fiji Is Affected by Climate Change-Cop23. 2017. Available online: https://cop23.com.fj/fiji-and-the-pacific/ how-fiji-is-affected-by-climate-change/ (accessed on 5 November 2020).

102. Ha'apio, M.; Wairiu, M.; Gonzalez, R.; Morrison, K. Transformation of rural communities: Lessons from a local self-initiative for building resilience in the Solomon Islands. Local Environ. 2018, 1-14. [CrossRef]

103. MECC-NEMO. Tonga: Joint National Action Plan on Climate Change Adaptation and Disaster Risk Management 2010-2015; GOT: Nuku'alofa, Tonga, 2010.

104. Maréchal, J.-P.; Hellio, C.; Hu, C. A simple, fast, and reliable method to predict Sargassum washing ashore in the Lesser Antilles. Remote Sens. Appl. Soc. Environ. 2017, 5. [CrossRef]

105. Prospero, J.M. Case study: Saharan dust impacts and climate change. Oceanography 2006, 19, 60. [CrossRef]

106. Confalonieri, U.; Menne, B.; Akhtar, R.; Ebi, K.L.; Haunegue, M.; Sari Kovats, R.; Revich, B.; Woodward, A. Human health. In Climate Change 2007: Impacts, Adaptation and Vulnerability; Cambridge University Press: Cambridge, UK, 2007 ; pp. 391-431.

107. Van Bortel, W.; Dorleans, F.; Rosine, J.; Blateau, A.; Rousset, D.; Matheus, S.; Leparc-Goffart, I. Chikungunya outbreak in the Caribbean region. Eurosurveillance 2014, 19. [CrossRef]

108. UNFCCC. Climate Change, Small Island Developing States; UNFCCC: Geneva, Switzerland, 2005.

109. Rongo, T.; Dyer, C. Using Local Knowledge to Understand Climate Variability in the Cook Islands, January 2015. UNDP Climate Change Adaptation. Available online: https:/ / www.adaptation-undp.org/resources/document/using-local-knowledgeunderstand-climate-variability-cook-islands-january-2015 (accessed on 7 November 2020).

110. PCCSP. Current and Future Climate of Samoa; Pacific Climate Change Science Programme; Samoa Meteorology Division, Ministry of Natural Resources and Environment: Apia, Samoa, 2011.

111. Aswani, S. Assessing the effects of changing demographic and consumption patterns on sea tenure regimes in the Roviana Lagoon, Solomon Islands. Ambio 2002, 31, 272-284. [CrossRef]

112. Rasmussen, K.; May, W.; Birk, T.; Mataki, M.; Mertz, O.; Yee, D. Climate change on three polynesian outliers in the Solomon Islands: Impacts, vulnerability and adaptation. Geogr. Tidsskr. 2009, 109, 1-13. [CrossRef]

113. Montz, B.E.; Tobin, G.A.; Hagelman, R.R. Natural Hazards: Explanation and Integration, 2nd ed.; The Guilford Press: New York, NY, USA, 2017.

114. Birk, T. Relocation of reef and atoll island communities as an adaptation to climate change? Learning from experience in Solomon Islands. In Climate Change and Human Mobility: Global Challenges to the Social Sciences; Cambridge University Press: Cambridge, UK, 2012.

115. MEECCDMMIC. Ministry of Environment Energy Climate Change Disaster Management Meteorology Information and Communication Tonga Mean Temperature Degree Celsius at Nuku'alofa; Government of Tonga: Nuku'alofa, Tonga, 2014. 
116. Leal Filho, W.; Modesto, F.; Nagy, G.J.; Saroar, M.; Toamukum, Y. Fostering coastal resilience to climate change vulnerability in Bangladesh, Brazil, Cameroon and Uruguay: A cross-country comparison. Mitig. Adapt. Strateg. Glob. Chang. 2018, 23, 579-602. [CrossRef]

117. Luetz, J.M. Climate change and migration in the Maldives: Some lessons for policy makers. In Climate Change Adaptation in Pacific Countries. Climate Change Management; Springer: Cham, Switzerland, 2017.

118. UNISDR-UNDP. United Nations International Strategy for Disaster Risk Reduction, United Nations Development Programme. Disaster Risk Reduction and Climate Change Adaptation in the Pacific: An Institutional and Policy Analysis; UNDP: New York, NY, USA, 2012. 